
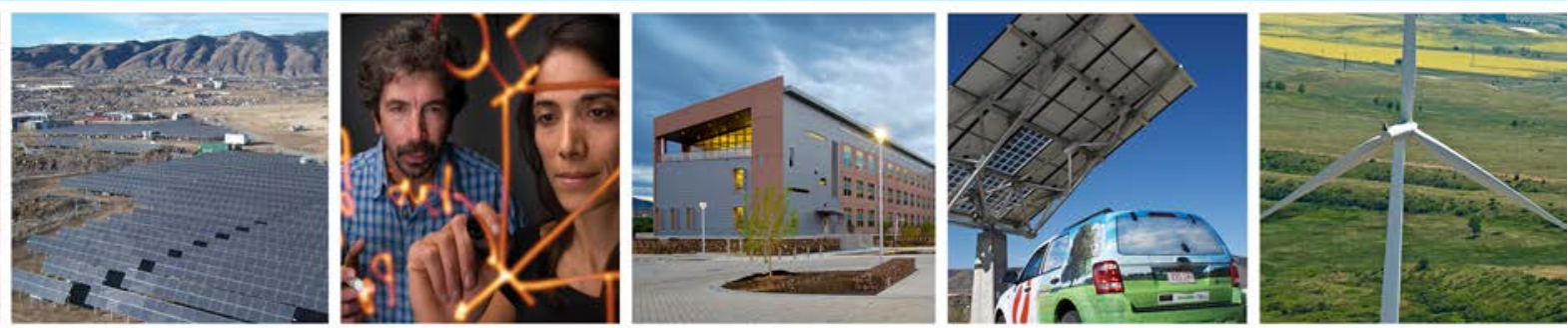

\title{
PVWatts Version 5 Manual
}

\author{
Aron P. Dobos
}

NREL is a national laboratory of the U.S. Department of Energy Office of Energy Efficiency \& Renewable Energy Operated by the Alliance for Sustainable Energy, LLC

This report is available at no cost from the National Renewable Energy Laboratory (NREL) at www.nrel.gov/publications.

\section{Technical Report}

NREL/TP-6A20-62641

September 2014

Contract No. DE-AC36-08G028308 


\section{PVWatts Version 5 Manual}

\section{Aron P. Dobos}

Prepared under Task No. SS13.5030

NREL is a national laboratory of the U.S. Department of Energy Office of Energy Efficiency \& Renewable Energy Operated by the Alliance for Sustainable Energy, LLC

This report is available at no cost from the National Renewable Energy Laboratory (NREL) at www.nrel.gov/publications. 


\title{
NOTICE
}

This report was prepared as an account of work sponsored by an agency of the United States government. Neither the United States government nor any agency thereof, nor any of their employees, makes any warranty, express or implied, or assumes any legal liability or responsibility for the accuracy, completeness, or usefulness of any information, apparatus, product, or process disclosed, or represents that its use would not infringe privately owned rights. Reference herein to any specific commercial product, process, or service by trade name, trademark, manufacturer, or otherwise does not necessarily constitute or imply its endorsement, recommendation, or favoring by the United States government or any agency thereof. The views and opinions of authors expressed herein do not necessarily state or reflect those of the United States government or any agency thereof.

This report is available at no cost from the National Renewable Energy Laboratory (NREL) at www.nrel.gov/publications.

Available electronically at http://www.osti.gov/scitech

Available for a processing fee to U.S. Department of Energy and its contractors, in paper, from:

\author{
U.S. Department of Energy \\ Office of Scientific and Technical Information \\ P.O. Box 62 \\ Oak Ridge, TN 37831-0062 \\ phone: 865.576 .8401 \\ fax: 865.576 .5728 \\ email: mailto:reports@adonis.osti.gov
}

Available for sale to the public, in paper, from:

U.S. Department of Commerce

National Technical Information Service

5285 Port Royal Road

Springfield, VA 22161

phone: 800.553 .6847

fax: 703.605.6900

email: orders@ntis.fedworld.gov

online ordering: http://www.ntis.gov/help/ordermethods.aspx

Cover Photos: (left to right) photo by Pat Corkery, NREL 16416, photo from SunEdison, NREL 17423, photo by Pat Corkery, NREL 16560, photo by Dennis Schroeder, NREL 17613, photo by Dean Armstrong, NREL 17436, photo by Pat Corkery, NREL 17721. 


\title{
PVWatts Version 5 Manual
}

\author{
Aron P. Dobos
}

September 4, 2014

\begin{abstract}
The NREL PVWatts ${ }^{\circledR}$ calculator is a web application developed by the National Renewable Energy Laboratory (NREL) that estimates the electricity production of a gridconnected photovoltaic system based on a few simple inputs. PVWatts combines a number of sub-models to predict overall system performance, and includes several built-in parameters that are hidden from the user. This technical reference manual describes the sub-models, documents hidden parameters and assumptions for default values, and explains the sequence of calculations that yield the final system energy production estimate. This reference applies to the significantly revised version of PVWatts released by NREL in 2014.
\end{abstract}

Keywords: photovoltaics, PVWatts, systems modeling, solar analysis

\section{Introduction and History}

PVWatts is a popular web application for estimating the energy production of a grid-connected photovoltaic (PV) system. It is designed to be simple to use and understand for non-experts and more advanced users alike. PVWatts hides much of the complexity of accurately modeling PV systems from the user by making several assumptions about the type, configuration, and operation of the system. Consequently, the results should be interpreted as being a representative estimate for a similar actual system operating in a year with typical weather. The errors may be as high as $\pm 10 \%$ for annual energy totals and $\pm 30 \%$ for monthly totals for weather data representing long-term historical typical conditions. Actual performance in a specific year may deviate from the long-term average up to $\pm 20 \%$ for annual and $\pm 40 \%$ for monthly values.

PVWatts has been online since 1999, and the original algorithms in version 1 were largely based on the approach of the Sandia PVFORM tool developed in the 1980s. A technical reference manual for PVWatts version 1 is available in [1]. Since then, several versions of PVWatts have been made available, though the system performance calculations have remained largely the same as version 1 . The version history is shown in Table 1.

In 2013, NREL began the process of revamping the PVWatts online web application to update the visual appeal and functionality, consolidate versions to reduce the ongoing maintenance burden, and update the energy prediction algorithms to be in line with the actual performance of modern photovoltaic systems.

While PVWatts is a useful tool for obtaining a quick estimate of energy production from a photovoltaic system, several more sophisticated tools are available for making more accurate predictions. The System Advisor Model (SAM) is a free desktop application developed by NREL that allows users to model PV systems in much greater detail [4]. SAM also includes detailed economic analysis for residential, commercial, and utility-scale systems, as well as performance models for concentrating solar power (CSP), wind, solar water heating, and geothermal systems. 
Table 1. Version History

\begin{tabular}{|c|c|c|c|c|}
\hline Version & Description & Weather Data Options & Date & Status \\
\hline V1 & Original online calculator. & $\begin{array}{l}239 \text { TMY2 sites. Added } \\
360 \text { international sites in } \\
2005 .\end{array}$ & 1998 & $\begin{array}{l}\text { Retiring } \\
\text { in } 2014\end{array}$ \\
\hline $\mathrm{V} 2$ & $\begin{array}{l}\text { Modified to utilize a gridded } 40 \mathrm{~km} \\
\text { monthly weather data in the continen- } \\
\text { tal US. Hourly calculations were done } \\
\text { with the nearest TMY2 site, and then } \\
\text { the monthly totals were scaled using the } \\
\text { monthly gridded weather data. }\end{array}$ & $\begin{array}{l}\text { Monthly } 40-\mathrm{km} \text { gridded ir- } \\
\text { radiance \& temperature } \\
\text { (CSR) }\end{array}$ & 2001 & $\begin{array}{l}\text { Retiring } \\
\text { in } 2014\end{array}$ \\
\hline SOAP & $\begin{array}{l}\text { A web service version of V2 using } \\
\text { the SOAP protocol for monthly predic- } \\
\text { tions. }\end{array}$ & Same as V2 & 2003 & $\begin{array}{l}\text { Retiring } \\
\text { in } 2014\end{array}$ \\
\hline V3 & $\begin{array}{l}\text { Web service version of the hourly } \\
\text { PVWatts V1 using the 10-km hourly } \\
\text { satellite-based irradiance dataset. In- } \\
\text { cluded a simplified economic cash flow } \\
\text { calculation. }\end{array}$ & $\begin{array}{l}\text { NREL/Clean Power } \\
\text { Research Perez 10-km } \\
\text { satellite-based irradiance, } \\
\text { typical files created from } \\
\text { 1998-2005 period of record }\end{array}$ & 2009 & $\begin{array}{l}\text { Defunct } \\
\text { in } 2012\end{array}$ \\
\hline V4 & $\begin{array}{l}\text { Updated REST-ful web } \\
\text { of the hourly PVWatts V1 on } \\
\text { http://developer.nrel.gov }\end{array}$ & $\begin{array}{l}239 \text { TMY2s, } 1020 \text { TMY3s, } \\
360 \text { International, } 10 \mathrm{~km} \\
\text { CPR/Perez 1998-2009 } \\
\text { typical satellite }\end{array}$ & 2012 & Operational \\
\hline V5 & $\begin{array}{l}\text { Completely new web application } \\
\text { user interface, updated calculation } \\
\text { engine (described here). } \\
\text { able at http://pvwatts.nrel.gov. } \\
\text { Also available as a web service on } \\
\text { http://developer.nrel.gov }\end{array}$ & $\begin{array}{l}1020 \text { Class I and II } \\
\text { TMY3s (default), } 239 \\
\text { TMY2s, } 360 \text { Interna- } \\
\text { tional, } 10 \mathrm{~km} \mathrm{CPR/Perez} \\
\text { 1998-2009 typical satellite }\end{array}$ & 2014 & $\begin{array}{l}\text { September } \\
2014\end{array}$ \\
\hline
\end{tabular}

PVsyst is another option for detailed PV performance modeling, and is a commercial software product [5].

\section{Overview of Changes in Version 5}

PVWatts version 5 is a comprehensive update of both default values and algorithms. The changes are designed to more accurately model typical systems while keeping the number of inputs to a minimum, and to provide a way to differentiate between common technology options without posing an undue technical burden upon the user.

For reference, previous versions of the PVWatts calculations are described in [1]. The key changes in PVWatts V5 are:

1. Option to select "Standard", "Premium", or "Thin film" module type.

2. Option to specify a DC-to-AC nameplate sizing ratio.

3. Module model no longer includes a quadratic correction at low light levels. 
4. Total system losses are specified as a percentage, with a default value of $14 \%$. This replaces the former DC-to-AC derate factor in PVWatts V1.

5. Inverter efficiency curve is derived from statistical analysis of data on inverters manufactured since 2010. The nominal inverter efficiency can be entered by the user.

6. One-axis tracking systems either estimate linear beam+diffuse self-shading losses based on row spacing, or use backtracking.

7. Albedo is fixed at 0.2 unless explicitly specified at each hour in a TMY3, EPW, or SAM/CSV weather file.

\section{$3 \quad$ Model Inputs}

PVWatts requires the minimal set of PV system specifications as listed in Table 2. Other performance parameters such as module temperature coefficients are hidden from the user.

Table 2. Input Parameters

\begin{tabular}{lll} 
Field & Units & Default Value \\
\hline System size & $\mathrm{kW}$ (DC) & 4 \\
Module type & Standard, Premium, Thin film & Standard \\
System losses & $\%$ & 14 \\
Array type & Fixed open rack, Fixed roof mount, 1-Axis, & Fixed open rack \\
& Backtracked 1-Axis, 2-Axis & \\
Tilt angle & degrees & Site Latitude \\
Azimuth angle & degrees & $180^{\circ}$ in northern hemi- \\
& & sphere, $0^{\circ}$ in southern \\
& & hemisphere \\
Advanced inputs & & 1.1 \\
\hline DC/AC ratio & ratio & 96 \\
Inverter efficiency & $\%$ & 0.4 \\
GCR (1 Axis only) & fraction &
\end{tabular}

The new module type input is designed to help differentiate between different technology options. The "standard" option represents typical poly- or mono-crystalline silicon modules, with efficiencies in the range of $14-17 \%$. The "premium" option is appropriate for modeling high efficiency ( $\sim 18-20 \%)$ monocrystalline silicon modules that have anti-reflective coatings and lower temperature coefficients. The thin film option assumes a low efficiency $(\sim 11 \%)$, and a significantly lower temperature coefficient which is representative of most installed thin film modules as of 2013. It is important to note that less common thin film module technologies may have quite different temperature coefficients than the default. The model assumptions for each model type are listed in Table 3 . It is up to the user to select the most appropriate option for the type of module being considered based on information on the module data sheet. The "standard" option is appropriate for typical preliminary analyses and is most similar to PVWatts V1.

The new advanced inputs allow the user to specify a DC-to-AC sizing ratio and ground coverage ratio, which was not possible in older versions of PVWatts. PVWatts V1 assumed that the DC nameplate capacity of the system was equal to the AC nameplate capacity. In modern 
Table 3. Assumptions for different module types

\begin{tabular}{lccc} 
Module type & Efficiency & Cover type & Temperature coefficient \\
\hline Standard & $\sim 15 \%$ & Glass & $-0.47 \% /{ }^{\circ} \mathrm{C}$ \\
Premium & $\sim 19 \%$ & Anti-reflective & $-0.35 \% /{ }^{\circ} \mathrm{C}$ \\
Thin film & $\sim 10 \%$ & Glass & $-0.20 \% /{ }^{\circ} \mathrm{C}$
\end{tabular}

systems, the photovoltaic array is often sized so that its DC rating is higher than the inverter's $\mathrm{AC}$ rating. Depending on location, this may be desirable to capture more energy during the beginning and end of the day, despite possibly clipping output at peak sun hours. The default value of the new DC-to-AC ratio input is 1.1 . For a $4 \mathrm{~kW} \mathrm{DC}$ system, this would result in a 3.63 $\mathrm{kW}$ AC inverter rating.

The ground coverage ratio (GCR) only applies to one axis tracking systems. It is a measure of the total module area relative to the roof or ground space occupied by the array. A GCR of 0.5 means that for a horizontal roof or ground surface, half of the total area is covered by modules when the tracker is rotated such that they are horizontal. A lower GCR means wider spacing between rows, and a higher one means that rows are spaced closer together. A GCR of 1 indicates no space between adjacent rows, and a GCR of 0 means essentially infinite spacing between rows. Typical one axis tracker systems have GCRs in the range of 0.3 to 0.6 , and the default value in PVWatts is 0.4. Previous versions of PVWatts effectively assumed a GCR of zero, which is impossible to achieve in practice.

\section{Solar Resource}

PVWatts requires hourly data for one year for two components of solar irradiance (beam and diffuse), ambient dry bulb temperature, and wind speed at $10 \mathrm{~m}$ above the ground. Each hour be timestamped with the year, month, day, and hour corresponding to the data line so that the sun position can be accurately calculated.

No adjustments are made for leap years or daylight savings time: hence, "hourly data" in this context implies 8,760 data points for one year. The required data are listed in Tables 4 and 5 .

Table 4. Header Information

\begin{tabular}{ll} 
Field & Units \\
\hline Latitude & degrees \\
Longitude & degrees \\
Time zone & hours offset from Greenwich Mean Time \\
Site elevation & meters above sea level
\end{tabular}

PVWatts can read solar resource data files from different sources and in different formats, including the National Solar Radiation Database (NSRDB) 1961-1990 data (TMY2) and 1991-2010 update (TMY3), and EnergyPlus weather files. It also reads files in the SAM CSV format [4], which is a generic format suitable for custom solar resource data sets. The PVWatts web application interacts with three online databases to access solar resource data, but does not allow users to specify their own weather data. 
Table 5. Hourly Input Data Fields

\begin{tabular}{ll} 
Field & Units/Values \\
\hline Year & $1950-2050$ \\
Month & $1-12$ \\
Day & $1-31$ \\
Hour & $0-23$ \\
Direct normal irradiance (DNI) & $\mathrm{W} / \mathrm{m}^{2}$ \\
Diffuse horizontal irradiance (DHI) & $\mathrm{W} / \mathrm{m}^{2}$ \\
Ambient dry bulb temperature & $\mathrm{Celsius}$ \\
Wind speed at 10 m & $\mathrm{m} / \mathrm{s}$ \\
Albedo (optional, typically in TMY3 files) & {$[0 . .1]$}
\end{tabular}

Change from PVWatts V1 In PVWatts V1, the albedo was changed to 0.6 for hours with a positive snow depth when using a TMY2 file. This increased system output, assuming the modules were cleaned regularly of any snow cover. Now, PVWatts assumes an albedo of 0.2 for all hours of the year for TMY2 files, and uses the hourly value provided in TMY3 files.

\section{Sun Position}

At each hour, PVWatts calculates the sun position using the algorithm described in [6]. The sun position is calculated at the midpoint of the hour: for example, from 2 p.m. to 3 p.m., the sun position is calculated at 2:30 p.m. to determine the solar zenith and azimuth angles. This is the case for normal daytime hours during which the sun is above the horizon for the whole hour.

For the sunrise hour, the midpoint between the sunrise time and the end of the timestep is used for the sun position calculation. Similarly, the midpoint between the beginning of the timestep and sunset time is used for the sunset hour.

\section{Tracking}

PVWatts performs angle of incidence (AOI) $(\alpha)$ calculations for fixed, one-axis, or two-axis tracking systems.

Fixed systems implement standard geometrical calculations for the angle of incidence given surface tilt $\beta$, surface azimuth $\gamma$, solar azimuth $\gamma_{\text {sun }}$, and solar zenith $\theta_{\text {sun }}$ angles, as listed in Eqn. 1.

$$
\alpha_{\text {fixed }}=\cos ^{-1}\left[\sin \left(\theta_{\text {sun }}\right) \cos \left(\gamma-\gamma_{\text {sun }}\right) \sin (\beta)+\cos \left(\theta_{\text {sun }}\right) \cos (\beta)\right]
$$

For one axis trackers, the algorithm documented in [10] is used. It assumes ideal tracking and does not account for any shading. The one-axis tracking algorithm assumes a hard-coded rotation limit of \pm 45 degrees from the horizontal. PVWatts uses a separate algorithm to calculate the fraction of each row that is shaded by adjacent rows based on the ground coverage ratio (GCR), and reduces the beam and diffuse irradiance incident on each row accordingly. When the backtracking option is enabled, PVWatts uses the SAM backtracking algorithm to avoid self-shading of adjacent rows. For details on these algorithms, consult [25]. 
Change from PVWatts V1 In PVWatts V1, one axis tracking assumed no selfshading or backtracking. This is an unrealistic assumption for most installed systems, as tracking rows cannot be spaced infinitely apart. Consequently, the production estimates for one axis tracked systems will be reduced relative to PVWatts V1.

For two axis tracking systems, the PV surface tilt and azimuth are set equal to the sun zenith angle and the sun azimuth angle, respectively, and the incidence angle is zero. The two axis tracking algorithm assumes no shading.

\section{Plane-of-Array Irradiance}

The plane-of-array (POA) beam, sky diffuse, and ground-reflected diffuse irradiance components are calculated using the Perez 1990 algorithm [7]. The POA beam component $I_{b}$ is simply the beam normal input multiplied by the cosine of the angle of incidence. The isotropic, circumsolar, and horizon brightening diffuse terms are calculated from the beam and diffuse input given two empirical functions F1 and F2 as defined and are summed to yield the total sky diffuse on the surface $I_{d, s k y}$. A slight modification from the standard Perez model treats the diffuse irradiance as isotropic for zenith angles between 87.5 and 90 degrees. The ground reflected irradiance $I_{d, \text { ground }}$ is treated as isotropic diffuse with a view factor calculated from the ground with respect to the tilted surface. The total POA incident on the module cover is the sum of the three components (Eqn. 2).

$$
I_{\text {poa }}=I_{b}+I_{d, s k y}+I_{d, \text { ground }}
$$

The albedo, or ground reflectance, is by default fixed at 0.2. When using TMY3 data as input, and valid data is found in the albedo column, the hourly albedo from the data file is used.

\section{Module Cover}

Given the total POA irradiance incident on the module cover, PVWatts applies an AOI correction to adjust the direct beam irradiance to account for reflection losses. The correction uses a modified version of the physical model of transmittance through a module cover used in [19].

PVWatts V5 gives users the option of "Standard", "Premium", or "Thin film" modules. For standard and thin film modules, PVWatts uses a single slab, calculating the transmittance through glass with index of refraction of 1.526. This follows the treatment in [19], with the simplification of removing the absorptance term which is determined (see below) to have a negligible effect.

For the premium module option, a two slab approach is used to model both the glass and the thin anti-reflective (AR) coating that is designed to improve the angular response. The two slab model involves predicting the transmittance of irradiance through two materials. The model applies the physical representation for unpolarized radiation described in [19] twice: once for the anti-reflective (AR) coating, and subsequently for the glass cover.

First, the angle of refraction $\theta_{2}$ into the AR coating is calculated with Snell's law given angle of incidence $\theta_{1}$ :

$$
\theta_{2}=\arcsin \left(\frac{n_{\text {air }}}{n_{A R}} \sin \left(\theta_{1}\right)\right)
$$




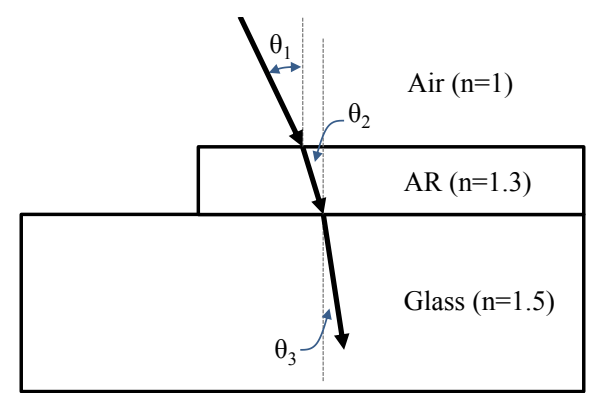

Figure 1. Diagram of two slab model

Next, the transmittance through the AR coating is calculated from Fresnel's equation for non-reflected unpolarized radiation, which takes the average of parallel and perpendicular components.

$$
\tau_{A R}=1-0.5 \frac{\sin \left(\theta_{2}-\theta_{1}\right)^{2}}{\sin \left(\theta_{2}+\theta_{1}\right)^{2}}+\frac{\tan \left(\theta_{2}-\theta_{1}\right)^{2}}{\tan \left(\theta_{2}+\theta_{1}\right)^{2}}
$$

The angle of refraction into the glass cover $\theta_{3}$ is again determined from Snell's law.

$$
\theta_{3}=\arcsin \frac{n_{A R}}{n_{\text {glass }}} \sin \left(\theta_{2}\right)
$$

The transmittance through the glass is calculated similarly given $\theta_{2}$ and $\theta_{3}$.

$$
\tau_{\text {glass }}=1-0.5 \frac{\sin \left(\theta_{3}-\theta_{2}\right)^{2}}{\sin \left(\theta_{3}+\theta_{2}\right)^{2}}+\frac{\tan \left(\theta_{3}-\theta_{2}\right)^{2}}{\tan \left(\theta_{3}+\theta_{2}\right)^{2}}
$$

Finally, the effective transmittance through the AR coated module cover is given by:

$$
\tau_{\text {cover }}=\tau_{A R} \tau_{\text {glass }}
$$

Desoto [19] suggests using Bouguer's law to estimate the absorption, but for typical dimensions $(\sim 2 \mathrm{~mm})$ and extinction coefficients $(K \approx 4)$ in this application, the absorption is predicted to be less than $0.1 \%$ and is thus ignored.

Given $n_{\text {air }}=1$ and $n_{\text {glass }}=1.526$, the angular response for two different indices of refraction for the AR coating is shown in Fig. 2. The model suggests that an AR coating yields an improvement in transmittance of about $3 \%$ relative to standard glass at normal incidence, which is commensurate with claims made by industry (Honeywell SOLARC [20], DSM Khepricoat [21]).

Normalizing the response curve to normal incidence shows that the model predicts an improvement in light capture at high incidence angles for AR glass, which agrees with data from manufacturers of AR coated modules (Fig. 3).

Change from PVWatts V1 In PVWatts V1, the angular response correction was only applied for incidence angles greater than 50 degrees. The new approach uses a physical model instead, which makes it possible to model typical differences between standard glass and anti-reflective glass. 


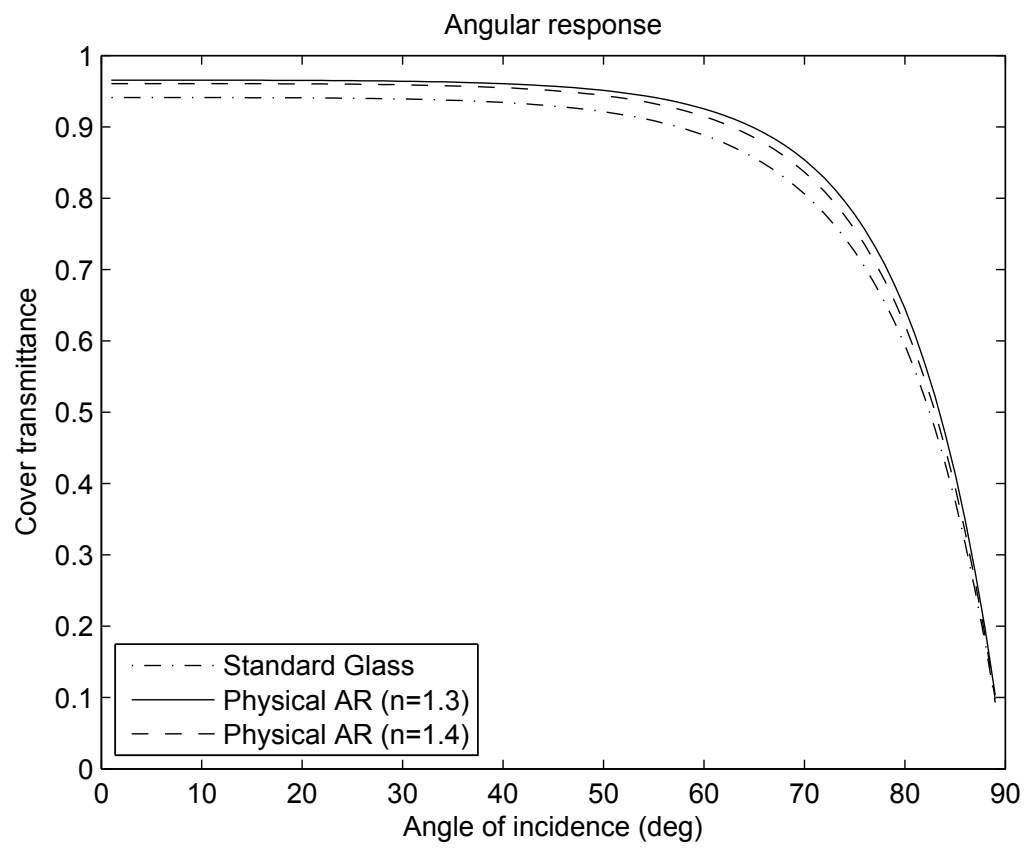

Figure 2. Two slab model angular response compared with single slab model

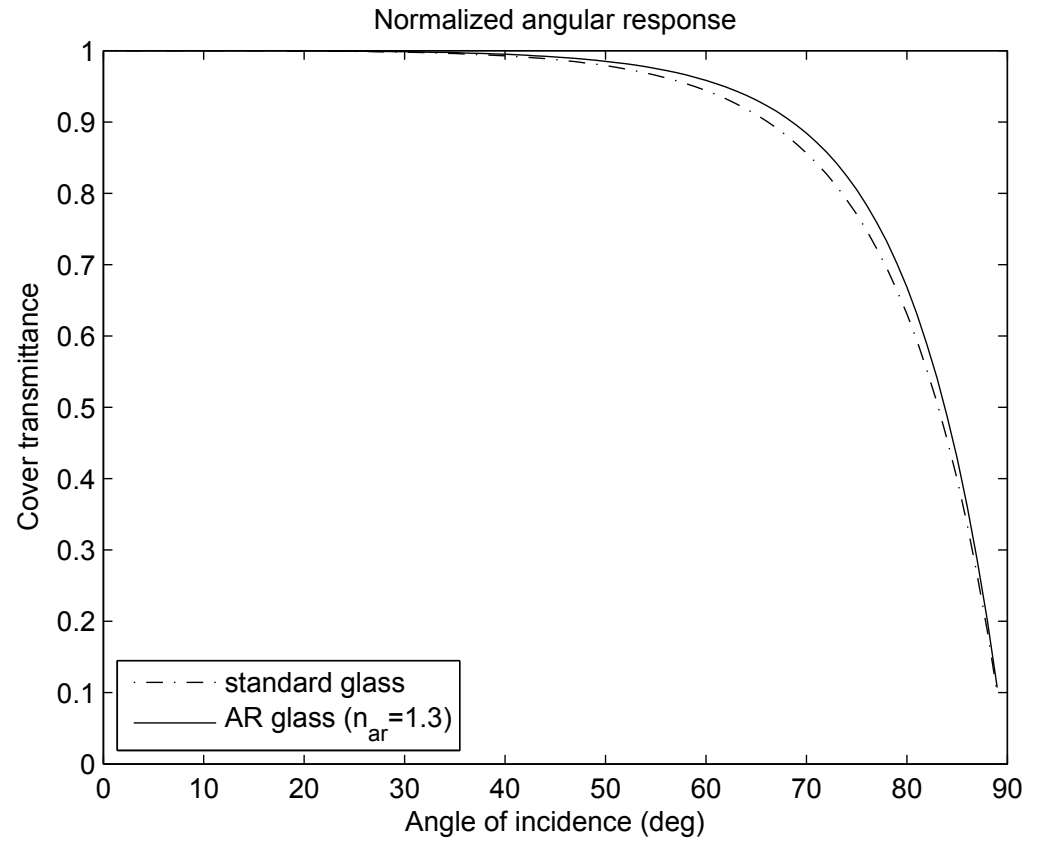

Figure 3. Two slab model angular response compared with single slab model - normalized 
The AR glass option will predict slightly higher output compared with the standard option due to the improved angular response. The normal incidence transmittance of the module cover is assumed to be captured in the nameplate rating of the system. The additional energy output due to the better angular response for AR glass is slight: for a fixed south-facing system in Texas, the anti-reflective coating yielded about $\sim 0.5 \%$ more energy on an annual basis. This will vary depending on location and system parameters.

\section{Thermal Model}

PVWatts implements a thermal model to calculate the operating cell temperature $T_{\text {cell }}$ using a first-principles heat transfer energy balance model developed by Fuentes [15]. The Fuentes model includes effects of the thermal capacitance of the module and performs a numerical integration between timesteps to account for the thermal lag transient behavior. The thermal model uses the total incident POA irradiance, wind speed, and dry bulb temperature to calculate the operating cell temperature. PVWatts assumes a height of $5 \mathrm{~m}$ above the ground when correcting the wind speed in the weather data, and that the installed nominal operating cell temperature (INOCT) of the module is $45^{\circ} \mathrm{C}$.

Change from PVWatts V1 In PVWatts V5, fixed systems may be mounted on an open rack or a roof mount. The selection changes the assumed INOCT based on the reduced air flow and thus higher operating temperature of a roof mount system.

The Fuentes paper discusses translation of the nominal operating cell temperature (NOCT) measured at standard conditions $\left(800 \mathrm{~W} / \mathrm{m} 2,20^{\circ} \mathrm{C}\right.$ ambient) to INOCT based on mounting configuration. For a roof mount system, air flow around the modules more restricted than on an open rack, and the installed nominal operating temperature will be higher. The estimate is for INOCT to be roughly $49^{\circ} \mathrm{C}$ for 4 inch standoffs. For fixed open rack and tracking systems, the original PVWatts V1 assumption of $45^{\circ} \mathrm{C}$ INOCT is retained.

\section{Module Model}

The PVWatts module computes the DC power from the array with a specified nameplate DC rating of $P_{d c 0}$ given a computed cell temperature $T_{c e l l}$ and transmitted POA irradiance $I_{t r}$. The array efficiency is assumed to decrease at a linear rate as a function of temperature rise, governed by temperature coefficient $\gamma$. The reference cell temperature $T_{r e f}$ is $25^{\circ} \mathrm{C}$, and reference irradiance is $1000 \mathrm{~W} / \mathrm{m}^{2}$.

$$
P_{d c}=\frac{I_{t r}}{1000} P_{d c 0}\left(1+\gamma\left(T_{c e l l}-T_{r e f}\right)\right)
$$

Change from PVWatts V1 In PVWatts V1, a quadratic correction was used to reduce the output for irradiance less than $125 \mathrm{~W} / \mathrm{m}^{2}$. In comparison with operating data from many systems, this behavior was not observed in modern systems, and thus the correction was removed.

The temperature coefficent depends on the module type selected. The values used were determined from a statistical analysis of over 11000 modules in the CEC module database, and are listed in Table 3.

Change from PVWatts V1 PVWatts V1 used a fixed temperature coefficient of $-0.5 \% /{ }^{\circ} \mathrm{C}$. The new values indicate improved performance of newer modules. 


\section{System Losses}

Losses in the system that are not explicitly modeled are provided by the user as a percentage of DC energy. Losses represented by this number include the impacts of soiling, shading, snow cover, mismatch, wiring, connections, light induced degradation, nameplate rating, system age, and operational availability. The default values are listed in Table 6 , alongside the related default derates used in PVWatts V1. In V5, all wiring losses are combined into one loss category, and the inverter is explicitly modeled. Consult [12] for more information on loss assumptions.

Table 6. System Losses

\begin{tabular}{lll} 
Loss mechanism & Default value & Related V1 Derate \\
\hline Soiling & $2 \%$ & 0.95 \\
Shading & $3 \%$ & 1.0 \\
Snow & $0 \%$ & 1.0 \\
Mismatch & $2 \%$ & 0.98 \\
Wiring & $2 \%$ & 0.98 \\
AC Wiring & - & 0.99 \\
Connections & $0.5 \%$ & 0.995 \\
Light-induced degradation & $1.5 \%$ & - \\
Nameplate rating & $1 \%$ & 0.95 \\
Age & $0 \%$ & 1.0 \\
Availability & $3 \%$ & 0.98 \\
Inverter & - & 0.92 \\
\hline Total losses & $14 \%$ (via Eqn. 9$)$ & 0.77
\end{tabular}

It is important to note that the total loss is not the sum of the individual losses. The total loss is calculated by multiplying the reduction due to each loss $L_{i}(\%)$ as shown in Eqn. 9. The default total system loss is calculated to be $14 \%$.

$$
L_{\text {total }}(\%)=100\left[1-\prod_{i} 1-\frac{L_{i}}{100}\right]
$$

The default assumption for shading losses represents blocking of the horizon due to faraway features such as large buildings, mountains, or other obstructions. Surveys of installed systems indicated that the average losses due to shading on systems described as "unshaded" was roughly $3 \%$ [14]. For a system experiencing shading due to nearby trees or structures, this loss value should be increased appropriately by using external shading software to predict shading losses, or with a onsite survey.

Light-induced degradation (LID) is a phenomenon in which the power output of a module decreases when it is exposed to sunlight for the first time. After this initial period, the module power stabilizes and subsequently follows typical long-term degradation over the lifetime of the installation ( $\sim 0.5 \%$ /year). The default light-induced degradation (LID) loss of $1.5 \%$ is a typical value based on measurements of losses in different module types [13]. Some premium modules may experience lower LID losses due to their materials and construction, while others may experience LID losses greater than $1.5 \%$. 
Change from PVWatts V1 PVWatts V1 used a DC-to-AC derate factor with a default value of 0.77 . The decision to switch to a system loss percentage input was made to bring PVWatts in line with common practice in the industry, and to make the inputs easier to understand for people not familiar with the concept of a derate factor. The inverter efficiency is not included in the system loss, and is a separate input parameter.

To approximately convert PVWatts V5 system loss to a PVWatts V1 DC-to-AC derate factor:

1. Convert the system loss to a derate: $1-14 / 100=0.86$.

2. Multiply this value by the nominal inverter efficiency: $0.86 \times 0.96=0.825$

This suggests that the default PVWatts V5 system loss represents roughly a $7 \%$ increase in system performance relative to PVWatts V1 due solely to updated input assumptions. The impact of the revised inverter efficiency curve in version 5 (described in next section) places the realized performance gain relative to V1 closer to 8-9 \% on an annual energy basis. This behavior is commensurate with hundreds of reports from PVWatts users, an expert survey solicitation, and calibration to numerous measured datasets that suggested that the old PVWatts derate was two conservative and underpredicted modern system performance by at least 8-9\% on average.

\section{Inverter Model}

The inverter model in PVWatts V5 is based on an analysis of California Energy Commission (CEC) inverter performance data. Inverters newer than 2010 were included in the analysis. A "typical" inverter was selected from the dataset by first calculating an average part-load efficiency curve, and then finding the actual inverter in the dataset whose actual efficiency curve was closest to the average. The efficiency data was then fitted to a quadratic loss model as presented in [22]. The resulting performance curve is given in Eqn. 10, which scales the efficiency curve to the nominal rated efficiency specified by the user $\eta_{\text {nom }}$. The reference inverter efficiency $\eta_{\text {ref }}$ from the CEC data for the actual most typical inverter is $0.9637\left(P_{a c 0} / P_{d c 0}\right)$, and AC nameplate rating $P_{a c 0}$ is determined from the $\mathrm{DC}$ rating of the system and the $\mathrm{DC}$-to-AC ratio. The default nominal efficiency $\eta_{\text {nom }}$ is 0.96 .

$$
\eta=\frac{\eta_{\text {nom }}}{\eta_{\text {ref }}} \quad-0.0162 \cdot \zeta-\frac{0.0059}{\zeta}+0.9858 \quad \text { where } \quad \zeta=\frac{P_{d c}}{P_{d c 0}} \quad \text { and } \quad P_{d c 0}=\frac{P_{a c 0}}{\eta_{n o m}}
$$

When the predicted AC output exceeds the nameplate rating, the output is clipped to the nameplate value. The inverter efficiency is shown in Fig. 4 for different nominal efficiencies, along with the original version 1 curve.

$$
P_{a c}= \begin{cases}\eta P_{d c} & : 0<P_{d c}<P_{d c 0} \\ P_{a c 0} & : P_{d c} \geq P_{d c 0} \\ 0 & : P_{d c}=0\end{cases}
$$




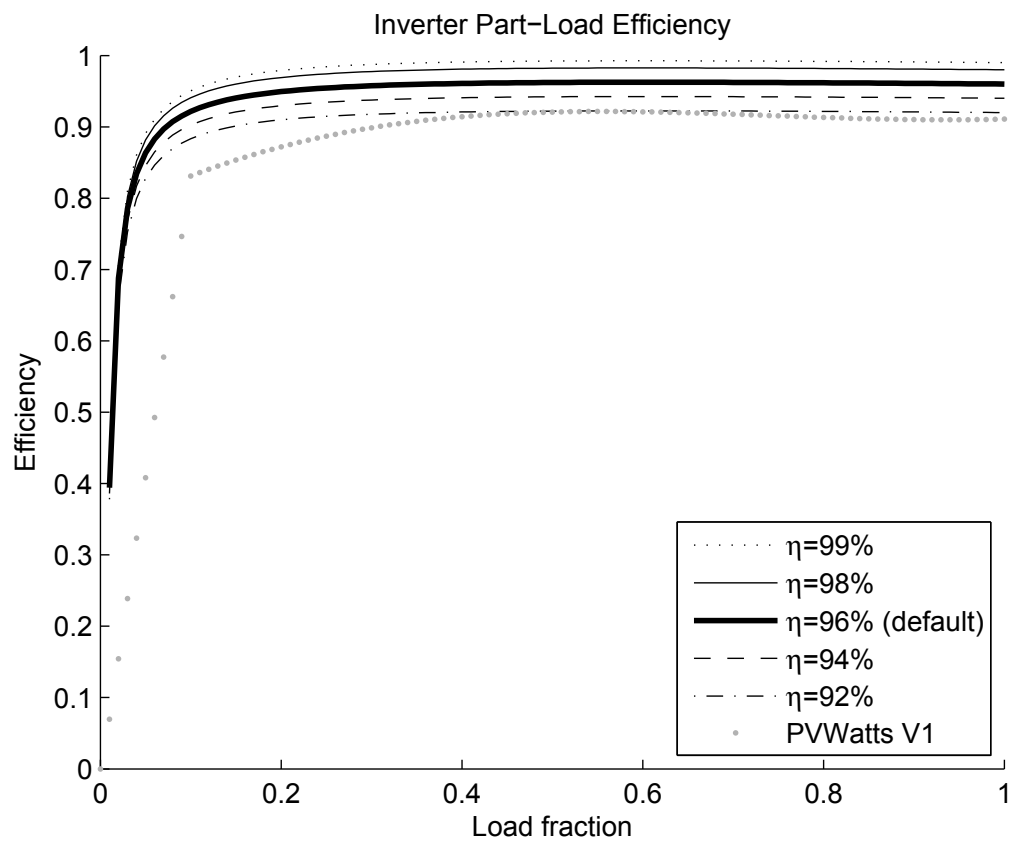

Figure 4. Inverter part-load efficiency curve

Table 7. Hourly Calculated Outputs

\begin{tabular}{ll} 
Field & Units \\
\hline Incident POA irradiance & $\mathrm{W} / \mathrm{m}^{2}$ \\
Transmitted POA irradiance & $\mathrm{W} / \mathrm{m}^{2}$ \\
DC power & $\mathrm{W}$ \\
AC power & $\mathrm{W}$
\end{tabular}

\section{Model Outputs}

PVWatts reports several hourly outputs based on the system specifications and hourly irradiance, temperature, and wind speed data. They are summarized in Table 7.

In addition, the average incident POA irradiance per day in each month is reported to the user. For each month $m$, the average POA in $\left(\mathrm{kW} / \mathrm{m}^{2} /\right.$ day $)$ is given by Eqn. 12 .

$$
P O A_{m}=\frac{0.001 \cdot \sum_{m} P O A_{h}}{\text { number of days in month } m}
$$

The hourly outputs DC and AC power are also aggregated into monthly and annual energy totals that are reported to the user. 


\section{Comparison with Version 1 Results}

Energy predictions of PVWatts V5 were compared to PVWatts V1 for several TMY2 locations. Several scenarios were considered:

1. Fixed: Fixed 20 degree tilt, south facing, standard module

2. Fixed+Premium: Fixed 20 degree tilt, south facing, premium module in PVWatts V5

3. 1 Axis: Self-shaded one axis tracking, GCR 0.4, standard module

4. Backtracking: Backtracked one axis tracking, GCR 0.4, standard module

5. 2 Axis: Two axis tracking, standard module

The number for each scenario reported in Table 8 is the percent difference between PVWatts V5 and V1 annual AC energy production estimates. The results show that PVWatts V5 predicts on average $8 \%$ percent more annual energy across all system configurations and locations. The one axis tracking cases show a lower increase - this is because PVWatts V1 overpredicts one axis tracking by assuming no self shading of rows. The greater relative improvement for fixed systems is due to the fact that fixed arrays operate more frequently at part-load since they do not track the sun, and so the effect of the improved part-load inverter efficiency is more pronounced.

\section{Comparison with Measured Data}

In this section, PVWatts predictions are shown for several systems. The nine systems considered are detailed in [23], and consist of 8 fixed tilt systems and one 1-axis tracked system. PVWatts V1 underpredicts system performance by $11.9 \%$ when comparing annual AC energy, while PVWatts V5 is low by only $1.8 \%$. All of the systems considered were unshaded, and the periods during which the system was unavailable were removed from the comparison. Consequently, the loss mechanisms for shading and availability were set to zero for both models. Systems with nonstandard module types were configured appropriately in PVWatts V5: system 2 (premium), system 7 (thin-film), and system 9 (thin-film).

In Figure 6, PVWatts V1 hourly results are shown for a fixed crystalline silicon system in Colorado. The data does not support the quadratic behavior at low power levels predicted by V1. PVWatts V5 does not include the module performance adjustment below $125 \mathrm{~W} / \mathrm{m}^{2}$, and thus matches the measured system data better. The PVWatts V1 low irradiance assumptions are not supported by any of the modern systems considered. In addition, the updated inverter performance curve in V5 tracks the measured system output more closely at high power outputs.

\section{Summary}

A comprehensive update to the popular PVWatts photovoltaic performance model was presented. The improved model formulation and updated default assumptions in V5 largely correct the underprediction of V1 relative to actual system performance. The updated PVWatts will be deployed to the NREL PVWatts Online Calculator in the fall of 2014, available at http://pvwatts.nrel.gov. 


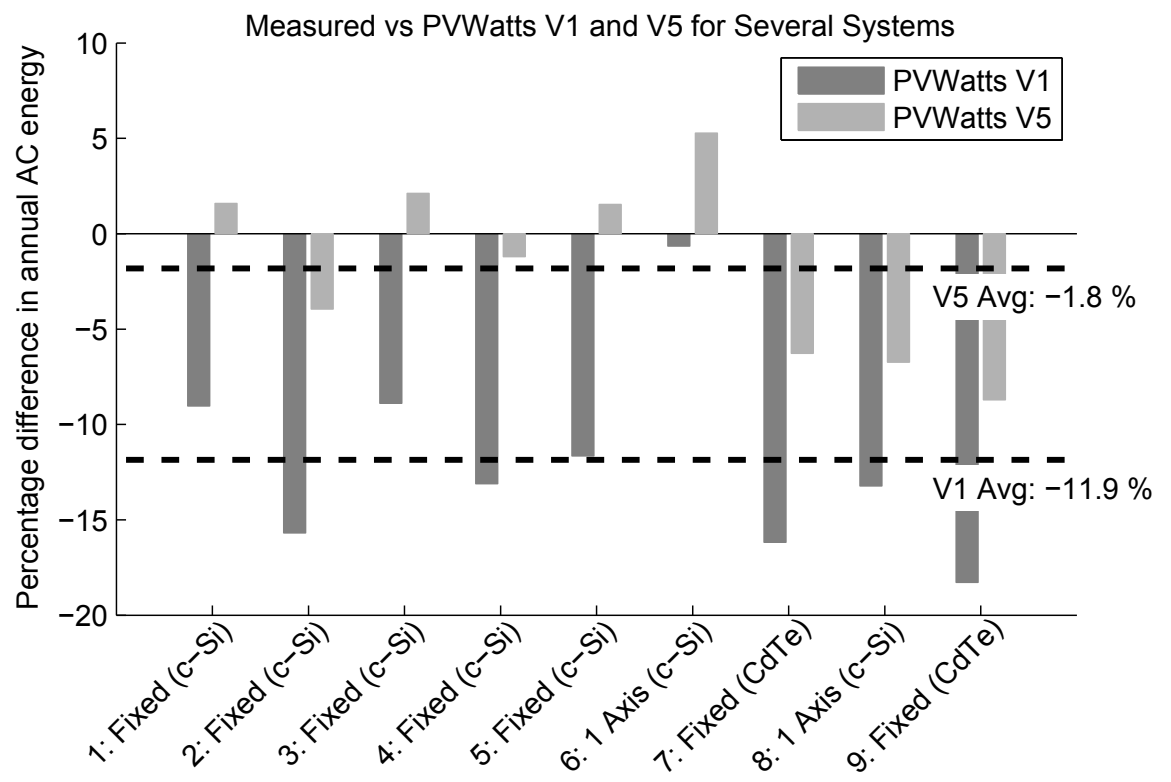

Figure 5. Comparision of PVWatts V1 and V5 AC energy prediction vs measured

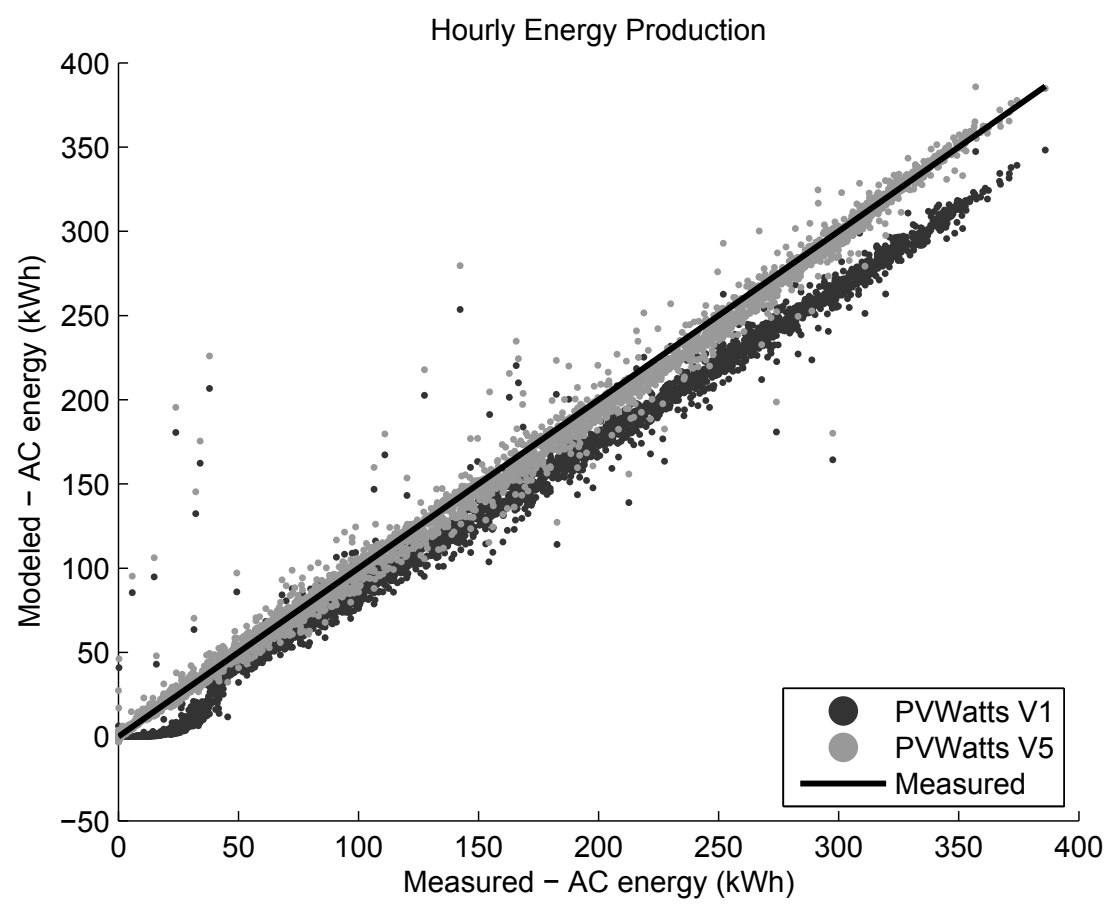

Figure 6. Hourly PVWatts V1 and V5 predictions vs measured 


\section{References}

[1] Dobos, A.; PVWatts Version 1 Technical Reference. . NREL/TP-6A20-60272. 2013.

[2] Marion, W.; Urban, K. (2012). User's Manual for TMY2. Accessed September 3, 2013: http://rredc.nrel.gov/solar/pubs/tmy2/.

[3] Wilcox, S.; Marion, W. (2008). User's Manual for TMY3 Data Sets. NREL/TP-581-43156. Golden, CO: National Renewable Energy Laboratory.

[4] NREL. System Advisor Model (SAM). http://sam.nrel.gov. 2014.

[5] PVsyst SA. PVsyst Photovoltaic Software Version 6.1. http://www.pvsyst.com. 2014.

[6] Michalsky, J. (1988). "The Astronomical Almanac's Algorithm for Approximate Solar Position (1950-2050)." Solar Energy (40).

[7] Perez, R.; Ineichen, P.; Seals, R.; Michalsky, J.; Stewart, R. (1990). "Modeling Daylight Availability and Irradiance Components for Direct and Global Irradiance." Solar Energy (44:5), pp. 271-289.

[8] Marion, W.; Anderberg, M. (2000). PVWATTS - An Online Performance Calculator for Grid-Connected PV Systems. Proceedings of the ASES Solar Conference, June 15-21, 2000, Madison, Wisconsin.

[9] Marion, W.; Anderberg, M.; George, R.; Gray-Hann, P.; Heimiller, D.; (2001) PVWATTS Version 2 - Enhanced Spatial Resolution for Calculating Grid-Connected PV Performance. CP-560-30941. Golden CO: National Renewable Energy Laboratory.

[10] Marion, W.; Dobos, A. P. (2013). Rotation Angle for the Optimum Tracking of One-Axis Trackers. TP-6A20-58891. Golden, CO: National Renewable Energy Laboratory.

[11] Marion, W. (2010). Overview of the PV Module Model in PVWatts. Presentation at the Sandia National Laboratories PV Performance Modeling Workshop, September 22, 2010, Albuquerque, New Mexico.

[12] Marion, W.; Adelstein, J.; Boyle, K.; Hayden, H.; Hammond, B.; Fletcher, T.; Canada, B.; Narang, D.; Shugar, D.; Wenger, H.; Kimber, A.; Mitchell, L.; Rich, G.; Townsend, T. (2005). Performance Parameters for Grid-Connected PV Systems. Proc. of 31st IEEE Photovoltaics Specialists Conference, January 2005, Lake Buena Vista, Florida.

[13] Pingel, S., Koshnicharov, D., Frank, O., Geipel, T., Zemen, Y., Striner, B., Berghold, J. Initial degradation of industrial silicon solar cells in solar panels. 25th EU PVSEC, 2010.

[14] Deline, C.; Meydbray, J.; Donovan, M.; Forrest, J.; Photovoltaic Shading Testbed for Module-level Power Electronics. NREL Technical Report NREL/TP-5200-54876, May 2012. http://www.nrel.gov/docs/fy12osti/54876.pdf

[15] Fuentes, M. K. (1987). A Simplified Thermal Model for Flat-Plate Photovoltaic Arrays. SAND85-0330. Albuquerque, NM: Sandia National Laboratories. Accessed September 3, 2013: http://prod.sandia.gov/techlib/access-control.cgi/1985/850330.pdf.

[16] California Energy Commission. (2013). "CEC PV Calculator Version 4.0." Accessed September 3, 2013: http://gosolarcalifornia.org/tools/nshpcalculator/index.php. 
[17] Menicucci, D. F.; Fernandez, J. P. (1988). User's Manual for PVFORM: A Photovoltaic System Simulation Program For Stand-Alone and Grid-Interactive Applications. SAND85-0376. Albuquerque, NM: Sandia National Laboratories. Accessed September 3, 2013: http://prod.sandia.gov/techlib/access-control.cgi/1985/850376.pdf.

[18] Menicucci, D. F. (1986). Photovoltaic Array Performance Simulation Models. Solar Cells (18).

[19] DeSoto, W.; Klein, S.; Beckman, W.; Improvement and Validation of a Model for Photovoltaic Array Performance. Solar Energy, vol.80, pp.78-88, 2006.

[20] Honeywell SOLARC. http://www.honeywell-pmt.com/sm/em/common/documents/SOLARC_antireflective_coating.pdf.

[21] DSM Khepricoat. https://www.dsm.com/content/dam/dsm/cworld/en_US/documents/khepricoatboosting-module-performance-with-a-durable-ar-coating.pdf

[22] Dreisse, A.; Jain, P.; Harrison, S.; Beyond the Curves: Modeling the Electrical Efficiency of Photovoltaic Inverters. Proc. IEEE Photovoltaic Specialists Conf., 2008.

[23] Freeman, J.; Whitmore, J.; Kaffine, L.; Blair, N.; Dobos, A.; System Advisor Model: Flat Plat Photovolatic Performance Modeling Validation Report. NREL/TP-6A20-60204, 2013.

[24] Freeman, J.; Whitmore, J.; Blair, N.; Dobos, A.; Validation of Multiple Tools for Flat Plate Photovoltaic Modeling Against Measured Data. NREL/TP-6A20-61497, 2014.

[25] Gilman, P.; SAM Photovoltaic Model Technical Reference. NREL/TP-6A20-xxxxx, forthcoming, 2014. 
Table 8. Comparison with PVWatts V1 for selected TMY2 locations

\begin{tabular}{|c|c|c|c|c|c|}
\hline Location & Fixed & Fixed+Premium & 1 Axis & Backtracking & 2 Axis \\
\hline AK Anchorage & $14.7 \%$ & $14.3 \%$ & $6.8 \%$ & $8.0 \%$ & $9.6 \%$ \\
\hline AL Huntsville & $9.7 \%$ & $11.2 \%$ & $4.9 \%$ & $5.9 \%$ & $8.5 \%$ \\
\hline AR Little Rock & $9.8 \%$ & $11.5 \%$ & $4.7 \%$ & $5.6 \%$ & $8.5 \%$ \\
\hline AZ Phoenix & $8.8 \%$ & $12.1 \%$ & $3.7 \%$ & $3.9 \%$ & $8.0 \%$ \\
\hline CA Sacramento & $9.2 \%$ & $11.2 \%$ & $4.0 \%$ & $4.5 \%$ & $8.2 \%$ \\
\hline CO Boulder & $8.9 \%$ & $10.2 \%$ & $3.3 \%$ & $3.9 \%$ & $7.3 \%$ \\
\hline CT Hartford & $10.2 \%$ & $10.7 \%$ & $5.0 \%$ & $6.3 \%$ & $8.0 \%$ \\
\hline DE Wilmington & $9.9 \%$ & $10.8 \%$ & $4.9 \%$ & $5.9 \%$ & $8.3 \%$ \\
\hline FL Miami & $9.4 \%$ & $11.5 \%$ & $4.7 \%$ & $5.7 \%$ & $8.3 \%$ \\
\hline GA Atlanta & $9.5 \%$ & $11.0 \%$ & $4.6 \%$ & $5.4 \%$ & $8.4 \%$ \\
\hline HI Honolulu & $8.7 \%$ & $10.9 \%$ & $3.0 \%$ & $3.4 \%$ & $7.8 \%$ \\
\hline IA Des Moines & $9.6 \%$ & $10.3 \%$ & $4.2 \%$ & $4.9 \%$ & $8.0 \%$ \\
\hline ID Boise & $9.4 \%$ & $10.6 \%$ & $3.2 \%$ & $3.6 \%$ & $8.1 \%$ \\
\hline IL Chicago & $10.1 \%$ & $10.7 \%$ & $4.7 \%$ & $5.7 \%$ & $8.4 \%$ \\
\hline IN Indianapolis & $10.0 \%$ & $10.8 \%$ & $4.9 \%$ & $6.0 \%$ & $8.5 \%$ \\
\hline KS Wichita & $9.3 \%$ & $10.4 \%$ & $4.0 \%$ & $4.6 \%$ & $8.0 \%$ \\
\hline KY Lexington & $10.1 \%$ & $11.0 \%$ & $5.0 \%$ & $6.0 \%$ & $8.7 \%$ \\
\hline LA New Orleans & $9.9 \%$ & $11.8 \%$ & $5.3 \%$ & $6.4 \%$ & $8.6 \%$ \\
\hline MA Boston & $9.8 \%$ & $10.2 \%$ & $4.7 \%$ & $5.7 \%$ & $8.0 \%$ \\
\hline MD Baltimore & $10.0 \%$ & $10.9 \%$ & $4.9 \%$ & $5.9 \%$ & $8.4 \%$ \\
\hline ME Portland & $9.6 \%$ & $9.8 \%$ & $3.9 \%$ & $4.8 \%$ & $6.9 \%$ \\
\hline MI Detroit & $10.5 \%$ & $10.9 \%$ & $4.9 \%$ & $6.1 \%$ & $8.2 \%$ \\
\hline MN Minneapolis & $9.5 \%$ & $9.8 \%$ & $3.7 \%$ & $4.5 \%$ & $6.9 \%$ \\
\hline MO Springfield & $9.6 \%$ & $10.8 \%$ & $4.4 \%$ & $5.1 \%$ & $8.3 \%$ \\
\hline MS Jackson & $9.8 \%$ & $11.6 \%$ & $5.2 \%$ & $6.2 \%$ & $8.5 \%$ \\
\hline MT Great Falls & $9.7 \%$ & $10.1 \%$ & $3.5 \%$ & $4.2 \%$ & $7.3 \%$ \\
\hline NC Charlotte & $9.7 \%$ & $11.2 \%$ & $4.9 \%$ & $5.8 \%$ & $8.5 \%$ \\
\hline ND Fargo & $9.6 \%$ & $9.6 \%$ & $3.3 \%$ & $4.1 \%$ & $6.6 \%$ \\
\hline NE Omaha & $9.5 \%$ & $10.4 \%$ & $4.2 \%$ & $5.0 \%$ & $7.5 \%$ \\
\hline NH Concord & $9.8 \%$ & $10.3 \%$ & $4.3 \%$ & $5.2 \%$ & $7.6 \%$ \\
\hline NJ Newark & $10.2 \%$ & $10.8 \%$ & $5.3 \%$ & $6.4 \%$ & $8.6 \%$ \\
\hline NM Albuquerque & $8.5 \%$ & $10.3 \%$ & $3.6 \%$ & $4.0 \%$ & $7.6 \%$ \\
\hline NV Las Vegas & $8.5 \%$ & $11.2 \%$ & $3.0 \%$ & $3.1 \%$ & $7.8 \%$ \\
\hline NY Albany & $10.2 \%$ & $10.6 \%$ & $4.4 \%$ & $5.4 \%$ & $8.0 \%$ \\
\hline OH Cleveland & $10.8 \%$ & $11.4 \%$ & $5.3 \%$ & $6.5 \%$ & $8.6 \%$ \\
\hline OK Tulsa & $9.5 \%$ & $10.8 \%$ & $4.2 \%$ & $4.9 \%$ & $8.4 \%$ \\
\hline OR Portland & $11.6 \%$ & $12.6 \%$ & $5.6 \%$ & $6.6 \%$ & $9.9 \%$ \\
\hline PA Harrisburg & $10.0 \%$ & $10.9 \%$ & $5.0 \%$ & $6.0 \%$ & $8.6 \%$ \\
\hline RI Providence & $9.8 \%$ & $10.2 \%$ & $4.8 \%$ & $5.8 \%$ & $8.1 \%$ \\
\hline SC Charleston & $9.5 \%$ & $11.1 \%$ & $4.7 \%$ & $5.5 \%$ & $8.4 \%$ \\
\hline SD Sioux Falls & $9.6 \%$ & $10.1 \%$ & $3.8 \%$ & $4.5 \%$ & $7.1 \%$ \\
\hline TN Chattanooga & $10.1 \%$ & $11.7 \%$ & $5.4 \%$ & $6.4 \%$ & $9.0 \%$ \\
\hline TX Abilene & $8.9 \%$ & $10.6 \%$ & $3.6 \%$ & $4.1 \%$ & $7.9 \%$ \\
\hline UT Salt Lake City & $9.4 \%$ & $10.9 \%$ & $3.6 \%$ & $4.1 \%$ & $7.8 \%$ \\
\hline VA Richmond & $9.8 \%$ & $10.9 \%$ & $4.8 \%$ & $5.7 \%$ & $8.4 \%$ \\
\hline VT Burlington & $10.1 \%$ & $10.3 \%$ & $4.1 \%$ & $5.1 \%$ & $7.4 \%$ \\
\hline WA Yakima & $9.8 \%$ & $11.2 \%$ & $3.3 \%$ & $3.7 \%$ & $8.1 \%$ \\
\hline WI Madison & $9.9 \%$ & $10.2 \%$ & $4.6 \%$ & $5.7 \%$ & $7.8 \%$ \\
\hline WV Elkins & $10.7 \%$ & $11.31 \%$ & $5.9 \%$ & $7.4 \%$ & $9.0 \%$ \\
\hline WY Cheyenne & $8.8 \%$ & $9.2 \%$ & $2.9 \%$ & $3.4 \%$ & $7.2 \%$ \\
\hline Avel & $9.8 \%$ & $10.9 \%$ & $4.4 \%$ & $5.3 \%$ & $8.1 \%$ \\
\hline
\end{tabular}

